\title{
Energy-level alignment at interfaces between manganese phthalocyanine and $\mathrm{C}_{60}$
}

\author{
Daniel Waas ${ }^{*}$, Florian Rückerl, Martin Knupfer ${ }^{*}$ and Bernd Büchner
}

\author{
Full Research Paper \\ Address: \\ IFW Dresden, P.O. Box 270116, D-01171 Dresden, Germany \\ Email: \\ Daniel Waas ${ }^{*}$ - d.waas@ifw-dresden.de; Martin Knupfer ${ }^{*}$ - \\ m.knupfer@ifw-dresden.de \\ * Corresponding author \\ Keywords: \\ $\mathrm{C}_{60}$; manganese phthalocyanine $(\mathrm{MnPc})$; organic interfaces; \\ photoelectron spectroscopy (PES)
}

Beilstein J. Nanotechnol. 2017, 8, 927-932.

doi:10.3762/bjnano.8.94

Received: 23 November 2016

Accepted: 22 March 2017

Published: 25 April 2017

This article is part of the Thematic Series "Towards molecular spintronics".

Guest Editor: G. Salvan

(C) 2017 Waas et al.; licensee Beilstein-Institut.

License and terms: see end of document.

\begin{abstract} (LUMOs) is rather small.

\section{Introduction}

Within the last decades we have witnessed considerable progress in the development and understanding of organic (opto-)electronic devices [1-10]. A key issue in any device is the energetics at the device interfaces as it determines charge transport across or charge separation at the corresponding interface $[11,12]$. Thus, it is not surprising that the investigation of organic semiconductor interfaces has a rather long history, and a large number of studies has resulted in an advanced understanding of such interfaces [11,13-25]. A significant step forward was achieved recently by the development of a theoretical framework which is able to reproduce previous experimental results and to provide a comprehensive overview over the possible energy level alignments [26].
\end{abstract}

We have used photoelectron spectroscopy to determine the energy-level alignment at organic heterojunctions made of manganese phthalocyanine $(\mathrm{MnPc})$ and the fullerene $\mathrm{C}_{60}$. We show that this energy-level alignment depends upon the preparation sequence, which is explained by different molecular orientations. Moreover, our results demonstrate that $\mathrm{MnPc} / \mathrm{C}_{60}$ interfaces are hardly suited for application in organic photovoltaic devices, since the energy difference of the two lowest unoccupied molecular orbitals
One class of materials that has been considered as constituents of organic devices quite often is the family of transition-metal phthalocyanines [27]. Indeed, several phthalocyanine-based (model) devices have been realized [28-33]. In particular, organic photovoltaic cells containing, e.g., copper phthalocyanine $(\mathrm{CuPc})$ can be found rather frequently in the literature [28,30,34-36]. There, the charge separation at interfaces between the phthalocyanine and an appropriate electron acceptor is a crucial process. Often, fullerenes $\left(\mathrm{C}_{60}\right)$ and their derivatives are used as acceptor materials.

Amongst the transition-metal phthalocyanines MnPc is exceptional in some respects. Due to the participation of manganese 
$3 \mathrm{~d}$ orbitals to the molecular electronic states close to the Fermi energy, MnPc differs significantly from other transition-metal phthalocyanines, as it is characterized by the smallest ionization potential, the largest electron affinity, the smallest band gap and the largest exciton-binding energy [37-42]. Furthermore, it has an unusual spin-state of the $\mathrm{Mn}^{2+}$ ion of $S=3 / 2$ and shows a weak ferromagnetic interaction in the bulk [43]. In this respect, thorough studies of $\mathrm{MnPc}$ in comparison to other transition-metal phthalocyanines (e.g., $\mathrm{CuPc}$ ) widens our knowledge and understanding of these systems and beyond.

In this contribution we present an investigation of the energy level alignment at $\mathrm{MnPc} / \mathrm{C}_{60}$ interfaces using photoelectron spectroscopy (PES). We show that this alignment depends on the preparation sequence and that the lowest unoccupied molecular orbitals (LUMOs) of the two molecules lie energetically very close at the interfaces, which is disadvantageous for applications in organic solar cells.

\section{Experimental}

We have carried out valence-band and core-level photoelectron spectroscopy studies of $\mathrm{MnPc} / \mathrm{C}_{60}$ interfaces at room temperature. The preparation and the analysis chamber had a base pressure of about $3 \cdot 10^{-10}$ mbar. For the measurements an X-ray tube XR-50-M with a monochromator Focus-500, a gas-discharge lamp UVS-300 and a hemispherical electron-energy analyzer PHOIBOS-150 (SPECS) were used. The energy scales were calibrated with the $\mathrm{Au} 4 \mathrm{f}_{7 / 2}$ core level emission feature of the substrate at $84.0 \mathrm{eV}$ binding energy and the Fermi cutoff ( $0 \mathrm{eV}$ binding energy) in the valence-band region. Furthermore, the valence-band spectra were corrected accounting for contributions of $\mathrm{He} \mathrm{I}_{\beta}$ and $\mathrm{HeI}_{\gamma}$ satellites, assuming they had the same shape, and intensities of $1.8 \%\left(\mathrm{He}_{\beta}\right)$ and $0.5 \%\left(\mathrm{He} \mathrm{I}_{\gamma}\right)$ of the
He $\mathrm{I}_{\alpha}$ signal with an energy shift towards lower binding energies of $1.87 \mathrm{eV}\left(\mathrm{He} \mathrm{I}_{\beta}\right)$ and $2.52 \mathrm{eV}\left(\mathrm{He} \mathrm{I}_{\gamma}\right)$, respectively. To obtain the correct secondary-electron cutoff a sample bias of $-5 \mathrm{eV}$ was applied. The total energy resolution of the spectrometer was $0.35 \mathrm{eV}$ for XPS and $0.15 \mathrm{eV}$ for the UPS measurements.

For our investigations a pre-cleaned $\mathrm{Au}(100)$ crystal, controlled by core-level PES spectra, was used as a substrate, on which the $\mathrm{MnPc} / \mathrm{C}_{60}$ heterojunctions were prepared. The fullerene and manganese phthalocyanine films were grown step by step at room temperature via evaporation of the two materials from home-built evaporators. The film thickness was monitored by a quartz crystal microbalance and additionally determined using the intensity change of the $\mathrm{Au} 4 \mathrm{f}_{7 / 2}$ core level peak according to the method established by Seah and Dench [44]. We have grown the interfaces under investigation by both deposition sequences, $\mathrm{MnPc}$ on $\mathrm{C}_{60}$ and vice versa. After each $\mathrm{MnPc}$ or $\mathrm{C}_{60}$ deposition step $\mathrm{C} 1 \mathrm{~s}, \mathrm{~N} 1 \mathrm{~s}, \mathrm{Mn} 2 \mathrm{p}$ and Au4f core-level and valence-band photoelectron spectra were measured in order to follow changes of the electronic structure and to determine the energy level alignment at the interfaces.

\section{Results and Discussion}

In Figure 1a and Figure 1b, we present the valence-band data as obtained from the freshly prepared gold substrate, from the starting layers of $\mathrm{C}_{60}$ and $\mathrm{MnPc}$, respectively, and from the organic heterojunctions $\mathrm{MnPc} / \mathrm{C}_{60}$ and $\mathrm{C}_{60} / \mathrm{MnPc}$ as a function of the respective layer thickness of the organic material on top. The corresponding layer thicknesses are displayed in these two figures. The spectra of pristine $\mathrm{C}_{60}$ and $\mathrm{MnPc}$ agree very well with those published earlier [39,41,45-49]. Upon deposition of the second organic material, the valence-band spectra change
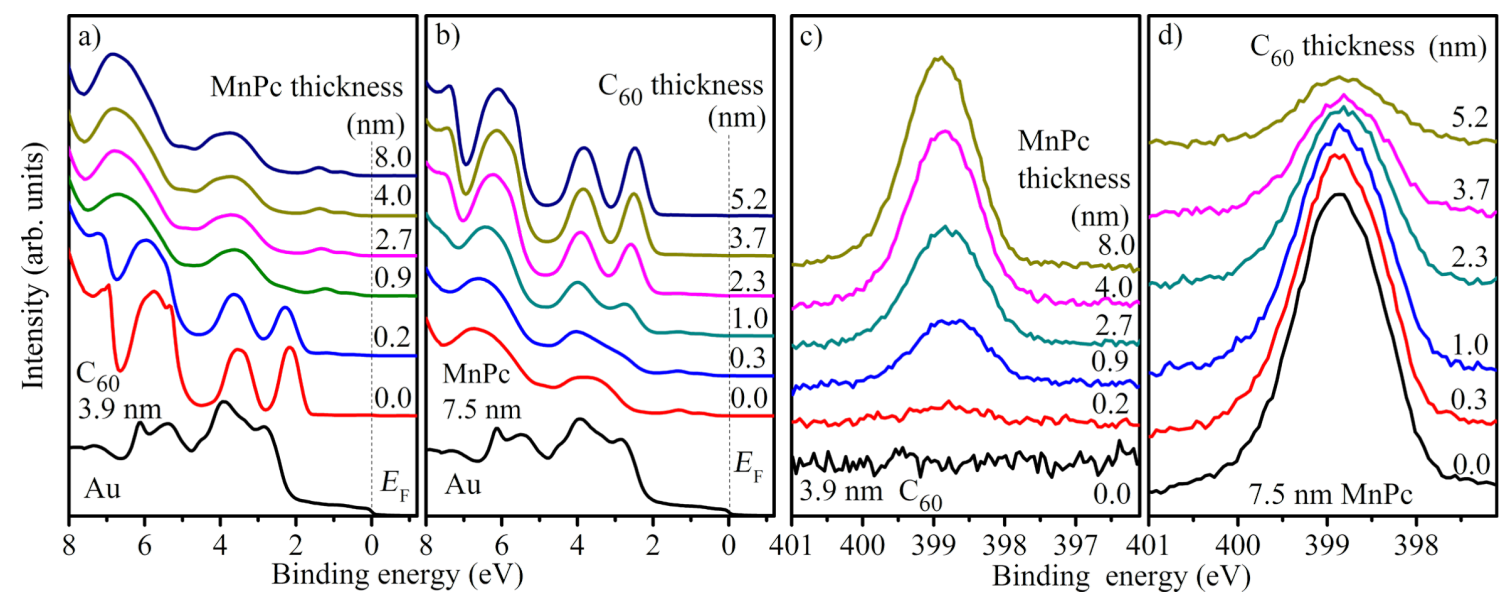

Figure 1: Evolution of the valence-band PES data $\left(\mathrm{He} \mathrm{I}_{\alpha}\right)$ as a function of a) MnPc deposition onto $\mathrm{C}_{60}$ and b) $\mathrm{C}_{60}$ deposition onto MnPc. Additionally the bottom spectrum represents the freshly prepared $\mathrm{Au}(100)$ surface. N1s core-level data of MnPc as a function of c) MnPc deposition onto $\mathrm{C}_{60}$ and d) $\mathrm{C}_{60}$ deposition onto $\mathrm{MnPc}$. The corresponding layer thicknesses are indicated. 
characteristically, the valence-band features of the second material, $\mathrm{MnPc}$ (Figure 1a) and $\mathrm{C}_{60}$ (Figure 1b), are observed and increase with increasing top-layer thicknesses until they are fully developed. In addition, there are energy shifts as a function of layer thickness, which indicate a change of the electrostatic potential at these interfaces as discussed below. There is no evidence for any additional contribution to the spectra and all spectra can be well described by a superposition of the spectra of pure $\mathrm{C}_{60}$ and MnPc. This clearly indicates the absence of chemical reactions at the interface studied here, as otherwise additional features or energy shifts would be expected.

We now turn to the discussion of the N1s core level data as obtained from the two deposition series, which are depicted in Figure 1c and Figure 1d. These data stem from MnPc only and, thus, allow insight into the behavior of one side of the interface under investigation. As a function of the corresponding overlayer thickness, the N1s core levels shift in energy, similar to what has been observed for the valence band data (see above). Apart from this energy shift, there are no significant changes in the measured line shapes except some broadening, which can be assigned to positional disorder right at the interface. This again indicates that the interface between $\mathrm{C}_{60}$ and $\mathrm{MnPc}$ is free of chemical reaction.

Unfortunately, the information that can be obtained from the $\mathrm{C} 1 \mathrm{~s}$ core levels (see Supporting Information File 1) is less clear, since the contributions of the two materials overlap. We therefore have analyzed only the peak positions from those data sets in which the assignment to the corresponding $\mathrm{MnPc}$ or $\mathrm{C}_{60}$ structures is clear. Moreover, potential (energy) changes occurring at the interface can also be followed looking at the secondary-electron cutoff, which represents the work function of the actual sample (see Supporting Information File 1). In Figure 2 we summarize all the energy shifts that are observed in valence- band, core-level and secondary-cutoff data for both deposition series in a relative manner. Inspection of this figure makes clear that going across the $\mathrm{MnPc} / \mathrm{C}_{60}$ interface, all available data shift in a very similar way. This is a strong indication for a common electrostatic potential for all electrons, in good agreement to our conclusions above that the $\mathrm{MnPc} / \mathrm{C}_{60}$ is free from chemical interactions at the interface.

From our data, we determined the energy-level alignments at the $\mathrm{MnPc} / \mathrm{C}_{60}$ interface for both deposition sequences, which are shown in Figure 3. The according energies for the highest occupied molecular orbitals (HOMOs) have been taken from those thicknesses of the respective overlayers, for which the energy changes as seen in Figure 2 are virtually saturated. Moreover, we also included the energy position of the lowest unoccupied orbitals (LUMOs), which are derived taking into account the energy gap of the two materials $\left(2.3 \mathrm{eV}\right.$ for $\mathrm{C}_{60}$ [46,50] and $1.2 \mathrm{eV}$ for $\mathrm{MnPc}$ [41]). Figure 3 indicates a rather large offset of the HOMOs of more than $1 \mathrm{eV}$ at the interface, while the energy positions of the LUMOs are much closer. These values are significantly different from those found for the interface between copper phthalocyanine $(\mathrm{CuPc})$ and $\mathrm{C}_{60}$, where the HOMO offset was reported to be about $0.9 \mathrm{eV}$ [51],

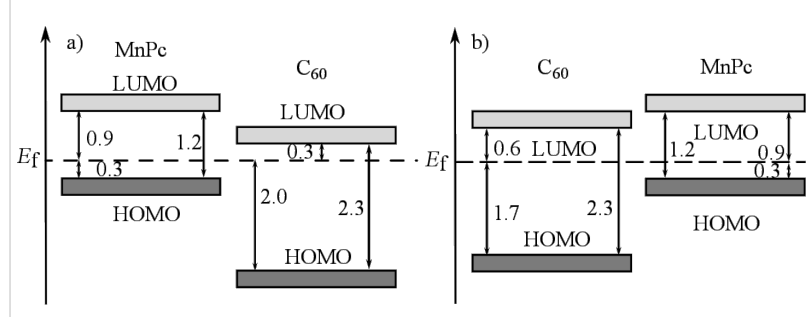

Figure 3: Schematic energy level diagrams of a) $M n P c / C_{60}$, when $C_{60}$ is deposited onto $\mathrm{MnPc}$ and b) $\mathrm{C}_{60} / \mathrm{MnPc}$, when $\mathrm{MnPc}$ is deposited onto $\mathrm{C}_{60}$. All values are given in electronvolts.
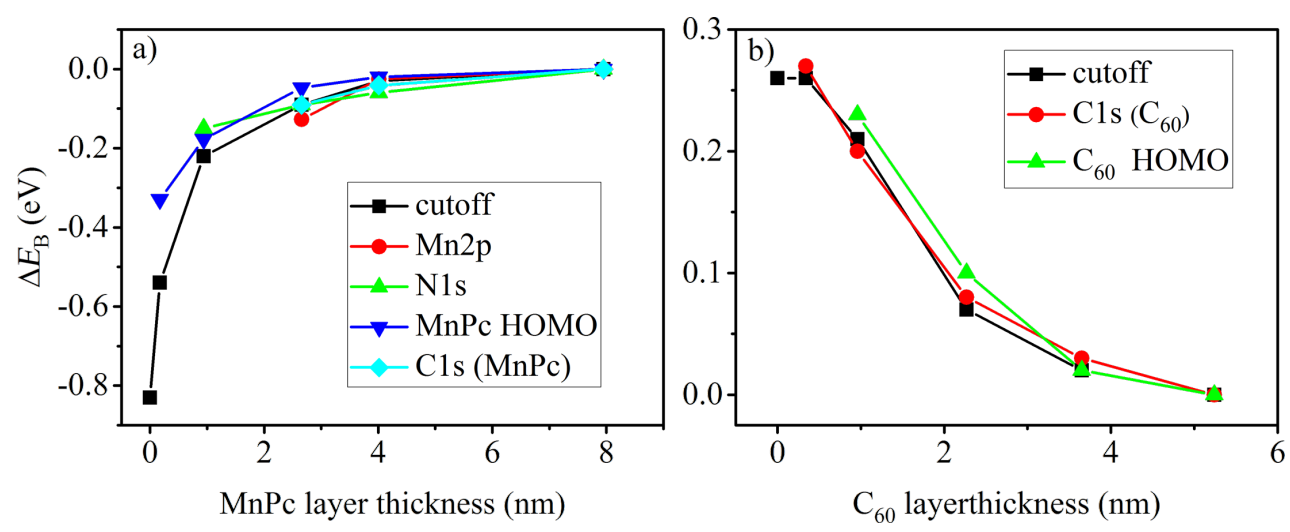

Figure 2: Comparison of the energy shifts of core levels, valence-band features and the secondary-electron cutoff (work function) of a) the $\mathrm{C}_{60} / \mathrm{MnPc}$ interface and $\mathrm{b}$ ) the $\mathrm{MnPc} / \mathrm{C}_{60}$ interface studied in this work. 
while the LUMO offset can be estimated to about $0.8 \mathrm{eV}$. This difference is predominantly due to the rather different energy gaps in $\mathrm{CuPc}$ (about $2.2 \mathrm{eV}$ [52]) and $\mathrm{MnPc}(1.2 \mathrm{eV})$. As a consequence, $\mathrm{MnPc} / \mathrm{C}_{60}$ junctions are less suited for the application in organic photovoltaic devices since the energy gain associated with the charge separation at the interface is significantly reduced.

Interestingly, the energy-level alignment at the interface between $\mathrm{MnPc}$ and $\mathrm{C}_{60}$, prepared on a gold substrate depends on the deposition sequence. The HOMO offset differs by about $0.3 \mathrm{eV}$. Furthermore, the position of the Fermi level in MnPc is identical for the two cases (Figure 3). This is in contrast to the $\mathrm{CuPc} / \mathrm{C}_{60}$ interface where the results were independent of the deposition sequence [51]. Following a recently introduced model [26], such a difference in the energy-level alignment would be expected, if the interaction of the organic layer deposited first and the metal substrate (gold) varies going from $\mathrm{MnPc}$ to $\mathrm{C}_{60}$ with the consequence of a different Fermi-level position in the layer stack. Moreover, in previous studies $[25,53]$ the importance of interface morphologies, molecular orientations and the resulting density of states on the energylevel alignment has been demonstrated. For instance, at the interface between $\mathrm{CuPc}$ and $\mathrm{F}_{16} \mathrm{CuPc}$ a significant change in the ionization potential and work function due to the molecular orientation was observed [54]. Also, the orientation of phthalocyanine molecules has been used to influence the $\mathrm{C}_{60}$ energy levels at respective junctions [55]. It is further known that $\mathrm{MnPc}$ and other transition-metal-phthalocyanine molecules grow in a flat lying manner on $\mathrm{Au}(100)[49,56]$, while on top of $\mathrm{C}_{60}$ they exhibit an edge-on orientation (i.e., they stand up) $[57,58]$. This then can cause a different energy-level alignment as the ionization depends on the molecular orientation in the layers [53].

Finally, comparing our results to those from an associated measurement of co-evaporated mixtures of $\mathrm{MnPc}$ and $\mathrm{C}_{60}$ [59] one can find many similarities. The behavior of the valence-band features upon changing the mixing ratio was found to be equivalent to the observed changes with increasing the layer thickness as shown above. Relative energy shifts parallel the behavior as seen in Figure 3.

\section{Conclusion}

We have determined the energy-level alignment at interfaces between $\mathrm{MnPc}$ and $\mathrm{C}_{60}$ using photoelectron spectroscopy studies. The relative energies at the interface depend on the deposition sequence. This is most likely a consequence of different growth modes of $\mathrm{MnPc}$ on either $\mathrm{Au}$ or $\mathrm{C}_{60}$ thin films. Moreover, our results show that at this interface the LUMO levels of $\mathrm{MnPc}$ and $\mathrm{C}_{60}$ lie energetically too close to render
$\mathrm{MnPc}$ an appropriate absorber material in organic photovoltaic cells in contrast to, e.g., CuPc.

\section{Supporting Information}

\section{Supporting Information File 1}

Additional spectra.

[http://www.beilstein-journals.org/bjnano/content/

supplementary/2190-4286-8-94-S1.pdf]

\section{Acknowledgements}

We thank M. Naumann, R. Hübel and S. Leger for technical assistance. Financial support by the Deutsche Forschungsgemeinschaft (Grant Nos. KN393/14, and KN393/25) is gratefully acknowledged.

\section{References}

1. Van Slyke, S.; Chen, C. H.; Tang, C. W. Appl. Phys. Lett. 1996, 69, 2160-2162. doi:10.1063/1.117151

2. Cicoira, F.; Santato, C. Adv. Funct. Mater. 2007, 17, 3421-3434. doi:10.1002/adfm.200700174

3. Dodabalapur, A. Mater. Today 2006, 9, 24-30. doi:10.1016/S1369-7021(06)71444-4

4. Rand, B. P.; Genoe, J.; Heremans, P.; Poortmans, J. Prog. Photovoltaics 2007, 15, 659-676. doi:10.1002/pip.788

5. Reineke, S.; Lindner, F.; Schwartz, G.; Seidler, N.; Walzer, K.; Lüssem, B.; Leo, K. Nature 2009, 459, 234-238. doi:10.1038/nature08003

6. Brabec, C. J.; Gowrisanker, S.; Halls, J. J. M.; Laird, D.; Jia, S.; Williams, S. P. Adv. Mater. 2010, 22, 3839-3856. doi:10.1002/adma.200903697

7. Klauk, H. Chem. Soc. Rev. 2010, 39, 2643-2666. doi:10.1039/b909902f

8. Sasabe, H.; Kido, J. Chem. Mater. 2011, 23, 621-630. doi:10.1021/cm1024052

9. Lüssem, B.; Tietze, M. L.; Kleemann, H.; Hoßbach, C.; Bartha, J. W.; Zakhidov, A.; Leo, K. Nat. Commun. 2013, 4, 2775. doi:10.1038/ncomms3775

10. Lu, L.; Zheng, T.; Wu, Q.; Schneider, A. M.; Zhao, D.; Yu, L. Chem. Rev. 2015, 115, 12666-12731.

doi:10.1021/acs.chemrev.5b00098

11. Koch, N. ChemPhysChem 2007, 8, 1438-1455. doi:10.1002/cphc. 200700177

12. Vandewal, K.; Albrecht, S.; Hoke, E. T.; Graham, K. R.; Widmer, J.; Douglas, J. D.; Schubert, M.; Mateker, W. R.; Bloking, J. T.; Burkhard, G. F.; Sellinger, A.; Fréchet, J. M. J.; Amassian, A.; Riede, M. K.; McGehee, M. D.; Neher, D.; Salleo, A. Nat. Mater. 2014, 13, 63-68. doi:10.1038/nmat3807

13. Ishii, H.; Sugiyama, K.; Ito, E.; Seki, K. Adv. Mater. 1999, 11, 605-625. doi:10.1002/(SICI)1521-4095(199906)11:8<605::AID-ADMA605>3.0.C $\mathrm{O} ; 2-\mathrm{Q}$

14. Scott, J. C. J. Vac. Sci. Technol., A 2003, 21, 521-531. doi:10.1116/1.1559919

15. Kahn, A.; Koch, N.; Gao, W. J. Polym. Sci., Part B: Polym. Phys. 2003, 41, 2529-2548. doi:10.1002/polb.10642 
16. Knupfer, M.; Paasch, G. J. Vac. Sci. Technol., A 2005, 23, 1072-1077. doi:10.1116/1.1885021

17. Braun, S.; Salaneck, W. R.; Fahlman, M. Adv. Mater. 2009, 21, 1450-1472. doi:10.1002/adma.200802893

18. Vázquez, H.; Gao, W.; Flores, F.; Kahn, A. Phys. Rev. B 2005, 71, 041306. doi:10.1103/PhysRevB.71.041306

19. Vázquez, H.; Dappe, Y. J.; Ortega, J.; Flores, F. Appl. Surf. Sci. 2007, 254, 378-382. doi:10.1016/j.apsusc.2007.07.047

20. Greiner, M. T.; Helander, M. G.; Tang, W.-M.; Wang, Z.-B.; Qiu, J.; Lu, Z.-H. Nat. Mater. 2012, 11, 76-81. doi:10.1038/nmat3159

21. Koch, N. Phys. Status Solidi RRL 2012, 6, 277-293. doi:10.1002/pssr.201206208

22. Ley, L.; Smets, Y.; Pakes, C. I.; Ristein, J. Adv. Funct. Mater. 2013, 23, 794-805. doi:10.1002/adfm.201201412

23. Oehzelt, M.; Koch, N.; Heimel, G. Nat. Commun. 2014, 5, 4174. doi:10.1038/ncomms5174

24. Akaike, K.; Koch, N.; Heimel, G.; Oehzelt, M. Adv. Mater. Interfaces 2015, 2, 2196-7350. doi:10.1002/admi.201500232

25. Opitz, A.; Wilke, A.; Amsalem, P.; Oehzelt, M.; Blum, R.-P.; Rabe, J. P.; Mizokuro, T.; Hörmann, U.; Hansson, R.; Moons, E.; Koch, N. Sci. Rep. 2016, 6, 21291. doi:10.1038/srep21291

26. Oehzelt, M.; Akaike, K.; Koch, N.; Heimel, G. Sci. Adv. 2015, 1, e1501127. doi:10.1126/sciadv.1501127

27. McKeown, N. B. Phthalocyanine materials: synthesis, structure and function; Cambridge University Press: Cambridge, United Kingdom, 1998.

28. Uchida, S.; Xue, J.; Rand, B. P.; Forrest, S. R. Appl. Phys. Lett. 2004, 84, 4218. doi:10.1063/1.1755833

29. Rand, B. P.; Cheyns, D.; Vasseur, K.; Giebink, N. C.; Mothy, S.; Yi, Y.; Coropceanu, V.; Beljonne, D.; Cornil, J.; Brédas, J.-L.; Genoe, J. Adv. Funct. Mater. 2012, 22, 2987-2995. doi:10.1002/adfm.201200512

30. Sullivan, P.; Jones, T. S.; Ferguson, A. J.; Heutz, S. Appl. Phys. Lett. 2007, 91, 233114. doi:10.1063/1.2821229

31. Ren, J.; Meng, S.; Kaxiras, E. Nano Res. 2012, 5, 248-257. doi:10.1007/s12274-012-0204-7

32. Kim, H. J.; Kim, J. W.; Lee, H. H.; Lee, B.; Kim, J.-J. Adv. Funct. Mater. 2012, 22, 4244-4248. doi:10.1002/adfm.201200778

33. Holzmueller, F.; Wilde, L.; Wölzl, F.; Koerner, C.; Vandewal, K.; Leo, K. Org. Electron. 2015, 27, 133-136. doi:10.1016/j.orgel.2015.08.031

34. Rusu, M.; Wiesner, S.; Lauermann, I.; Fischer, C.-H.; Fostiropoulos, K.; Audinot, J. N.; Fleming, Y.; Lux-Steiner, M. C. Appl. Phys. Lett. 2010, 97, 073504. doi:10.1063/1.3481395

35. Jeong, W.-I.; Lee, Y. E.; Shim, H.-S.; Kim, T.-M.; Kim, S.-Y.; Kim, J.-J. Adv. Funct. Mater. 2012, 22, 3089-3094. doi:10.1002/adfm.201200069

36. Lo, M. F.; Ng, T. W.; Liu, T. Z.; Roy, V. A. L.; Lai, S. L.; Fung, M. K.; Lee, C. S.; Lee, S. T. Appl. Phys. Lett. 2010, 96, 113303. doi:10.1063/1.3360336

37. Fielding, P. E.; MacKay, A. G. Aust. J. Chem. 1964, 17, 750-758. doi:10.1071/CH9640750

38. Grobosch, M.; Aristov, V. Yu.; Molodtsova, O. V.; Schmidt, C.; Doyle, B. P.; Nannarone, S.; Knupfer, M. J. Phys. Chem. C 2009, 113, 13219-13222. doi:10.1021/jp901731y

39. Grobosch, M.; Mahns, B.; Loose, C.; Friedrich, R.; Schmidt, C. Kortus, J.; Knupfer, M. Chem. Phys. Lett. 2011, 505, 122-125. doi:10.1016/j.cplett.2011.02.039

40. Kraus, R.; Grobosch, M.; Knupfer, M. Chem. Phys. Lett. 2009, 469, 121-124. doi:10.1016/j.cplett.2008.12.090

41. Haidu, F.; Fechner, A.; Salvan, G.; Gordan, O. D.; Fronk, M.; Lehmann, D.; Mahns, B.; Knupfer, M.; Zahn, D. R. T. AIP Adv. 2013, 3, 062124. doi: $10.1063 / 1.4812230$
42. Lever, A. B. P.; Milaeva, E. R.; Speier, G. In Phthalocyanines Properties and Applications; Leznoff, C. C.; Lever, A. B. P., Eds.; VCH Publishers: Weinheim, Germany, 1993.

43. Barraclough, C. G.; Martin, R. L.; Mitra, S.; Sherwood, R. C. J. Chem. Phys. 1970, 53, 1638-1642. doi:10.1063/1.1674236

44. Seah, M. P.; Dench, W. A. Surf. Interface Anal. 1979, 1, 2-11. doi:10.1002/sia.740010103

45. Benning, P. J.; Poirier, D. M.; Troullier, N.; Martins, J. L.; Weaver, J. H.; Haufler, R. E.; Chibante, L. P. F.; Smalley, R. E. Phys. Rev. B 1991, 44, 1962. doi:10.1103/PhysRevB.44.1962

46. Lof, R. W.; van Veenendaal, M. A.; Koopmans, B.; Jonkman, H. T.; Sawatzky, G. A. Phys. Rev. Lett. 1992, 68, 3924. doi:10.1103/PhysRevLett.68.3924

47. Knupfer, M. Surf. Sci. Rep. 2001, 42, 1-74. doi:10.1016/S0167-5729(00)00012-1

48. Veenstra, S. C.; Heeres, A.; Hadziioannou, G.; Sawatzky, G. A.; Jonkman, H. T. Appl. Phys. A 2002, 75, 661-666. doi:10.1007/s003390201311

49. Petraki, F.; Peisert, H.; Hoffmann, P.; Uihlein, J.; Knupfer, M.; Chassé, T. J. Phys. Chem. C 2012, 116, 5121-5127. doi:10.1021/jp211445n

50. Benning, P. J.; Poirier, D. M.; Ohno, T. R.; Chen, Y.; Jost, M. B.; Stepniak, F.; Kroll, G. H.; Weaver, J. H.; Fure, J.; Smalley, R. E. Phys. Rev. B 1992, 45, 6899. doi:10.1103/PhysRevB.45.6899

51. Molodtsova, O. V.; Knupfer, M. J. Appl. Phys. 2006, 99, 3704. doi:10.1063/1.2175468

52. Zahn, D. R. T.; Gavrila, G. N.; Gorgoi, M. Chem. Phys. 2006, 325, 99-112. doi:10.1016/j.chemphys.2006.02.003

53. Duhm, S.; Heimel, G.; Salzmann, I.; Glowatzki, H.; Johnson, R. L.; Vollmer, A.; Rabe, J. P.; Koch, N. Nat. Mater. 2008, 7, 326-332. doi:10.1038/nmat2119

54. Chen, W.; Huang, H.; Chen, S.; Huang, Y. L.; Gao, X. Y.; Wee, A. T. S. Chem. Mater. 2008, 20, 7017-7021. doi:10.1021/cm8016352

55. Mao, H. Y.; Wang, R.; Huang, H.; Wang, Y. Z.; Gao, X. Y.; Bao, S. N.; Wee, A. T. S.; Chen, W. J. Appl. Phys. 2010, 108, 053706. doi:10.1063/1.3475716

56. Lindner, S.; Mahns, B.; Treske, U.; Vilkov, O.; Haidu, F.; Fronk, M.; Zahn, D. R. T.; Knupfer, M. J. Chem. Phys. 2014, 141, 094706. doi:10.1063/1.4894757

57. Huang, H.; Chen, W.; Chen, S.; Qi, D. C.; Gao, X. Y.; Wee, A. T. S. Appl. Phys. Lett. 2009, 94, 163304. doi:10.1063/1.3122940

58. Schünemann, C.; Wynands, D.; Wilde, L.; Hein, M. P.; Pfützner, S.; Elschner, C.; Eichhorn, K.-J.; Leo, K.; Riede, M. Phys. Rev. B 2012, 85, 245314. doi:10.1103/PhysRevB.85.245314

59. Roth, F.; Herzig, M.; Lupulescu, C.; Darlatt, E.; Gottwald, A.; Knupfer, M.; Eberhardt, W. J. Appl. Phys. 2015, 118, 185310. doi:10.1063/1.4935623 


\section{License and Terms}

This is an Open Access article under the terms of the Creative Commons Attribution License

(http://creativecommons.org/licenses/by/4.0), which permits unrestricted use, distribution, and reproduction in any medium, provided the original work is properly cited.

The license is subject to the Beilstein Journal of Nanotechnology terms and conditions:

(http://www.beilstein-journals.org/bjnano)

The definitive version of this article is the electronic one which can be found at:

doi:10.3762/bjnano.8.94 